\title{
PENGARUH TERPAAN MEDIA TELEVISI TENTANG PEMBERITAAN KASUS PEMBEGALAN MOTOR TERHADAP TINGKAT KECEMASAN MAHASISWA PRODI ILMU KOMUNIKASI UIN SUNAN AMPELSURABAYA
}

\author{
Fairuzah Rahmi ${ }^{1}$, Syaifudin Zuhri $^{2}$
}

${ }^{1-2}$ Universitas Islam Negeri Sunan Ampel Surabaya

1fairuzah@gmail.com, 2syaifudinzuhri@uinsby.ac.id

Article Info

Article history:

Received 16 August 2018

Accepted 15 September 2018

Published 10 Oktober 2018

Keyword:

Berita, pembegalan motor,

tingkat kecemasan
Abstract

Artikel ini membahas tentang: Apakah ada pengaruh menonton Pemberitaan Pembegalan Motor terhadap Tingkat Kecemasan Mahasiswa Prodi Ilmu Komunikasi Universitas Islam Negeri Sunan Ampel? Untuk mengungkap persoalan tersebut secara menyeluruh dan mendalam, dalampenelitian ini digunakan metode kuesioner terhadap mahasiswa UIN Sunan Ampel Surabaya.

Dari hasil penelitian ini ditemukan (1) Ada pengaruh terpaan media televisi tentang pemberitaan pembegalan motor terhadap tingkat kecemasan mahasiswa Prodi Ilmu Komunikasi Universitas Islam Negeri Sunan Ampel

(2) Tingkat pengaruh sebesar 0,802 dengan menggunakan Uji Analisis produk momen (Rxy) dibuktikan dengan melihat nilai rhitung rtabel $=0,802>0,284$ yang berarti ho ditolak dan ha diterima. Adanya pengaruh atau tidak juga dapat dilihat pada tabel correlation product moment, dimana nilai signifikansi bernilai 0,000 yang berarti ho ditolak dan ha diterima.

Karena hasil koefisiensi korelasi tersebut bersifat positif. Untuk mengetahui seberapa besar pengaruhnya maka peneliti menggunakan uji korelasisederhana (uji t), dimana nilai t hitung > t tabel, 9,306 > 2,021 dan p value $0,000<$ 0,005, maka ho ditolak dan ha diterima, artinya dapat disimpulkan bahwa terpaan media televisi tentang pemberitaan pembegalan motor terhadap tingkat kecemasan mahasiswa Prodi Ilmu Komunikasi Universitas Islam Negeri Sunan Ampel. 


\section{Pendahuluan}

Media televisi sangat berperan penting dalam membentuk berbagai persepsi di kalangan masyarakat terutama di kalangan para mahasiswa, Siaran televisi saat ini telah menjadi suatu kekuatan yang sudah merasuk ke dalam kehidupan masyarakat. Televisi sebagai media massa memiliki karakteristik tersendiri yang berbeda dengan media lain di dalam penyampaian pesannya. Salah satu kelebihan televisi yaitu paling lengkap dalam hal menyajikan unsur-unsur pesan bagi khalayak pemirsa, oleh karena dilengkapi gambar dan suara terasa lebih hidup dan dapat menjangkau ruang lingkup yang sangat luas.

Hampir setiap hari media televisi ini meberitakan tentang kasus penganiayaan, pembunuhan, perampokan, pencurian, pemerkosaan, dan berbagai tindak kejahatan lainnya. Akhir - akhir ini banyak pemberitaan tentang pembegalan motor yang meresahkan masyarakat, dari berbagai pemberitaan tersebut mirisnya pelaku tindak kejahatan pembegalan motor di lakukan oleh para remaja yang usianya masih di bawah umur.

Seperti kasus Pembegalan Motor yang terjadi di Pondok Aren Tangerang yang korbanya adalah seorang wanita selain itu pelaku tidak segan - segan untuk melukai korbannya jika korban tersebut melawan.

Menurut Eriyanto menyatakan bahwa berita bukan sekedar menyampaikan berita , tetapi menyampaikan makna. Berita - berita yang ada di media massa terutama media televisi bukanlah susunan kata - kata dan kalimat yang tidak ada makna atau maksudnya. Makna tersebut ditentukan oleh wartawan yang menulis cerita, latar belakang wartawan akan sangat mempengaruhi wartawan ketika ia memutuskan fakta mana yang akan di tulis dan fakta mana yang akan di buang,serta fakta mana yang akan di tonjolkan dan fakta mana yang harus disamarkan. ${ }^{1}$

Karena itulah isi berita media elektronik televisi yang memberi informasi dapat mempengaruhi sikap masyarakat, baik sikap, perilaku, dan hal - hal lainnya.Termasuk dalam hal mempengaruhi kepedulian, kecemasan pemirsa terhadap situasi yang ada.Sikap sendiri terdiri dari kognitif, afektif, dan konatif, sedangkan kecemasan merupakan bagian dari sikap afektif.

Fenomena pemberitaan tentang pembegalan motor ini mengakibatkan kecemasan para masyarakat terutama mahasiswa untuk berpergian pada malam hari di karenakan dalam pemberitaan yang di tayangkan di televisi sekelompok kawanan pembegal melakukan aksinya di malam hari. Gencarnya berita pembegalan menimbulkan kekhawatiran akan terbentuknya persepsi dan sikap atau karakter negatif yang kuat. Sehingga memunculkan pertanyaan mengenai bagaimana siaran berita pembegalan motor dapat menimbulkan kecemasan di kalangan mahasiswa.

\footnotetext{
${ }^{1}$ Fisher, B. Aubrey, 1989, Teori-teori Komunikasi, Soejono Trimo (penerjemah) Bandung: Remadja Karya.hal 112
} 


\section{Kajian Pustaka}

\section{Konsep Terpaan Media}

Terpaan dapat diartikan sebagai kegiatan mendengar, melihat, dan membaca pesan-pesan media atau pun mempunyai pengalaman dan perhatian terhadap pesan tersebut yang dapat terjadi pada individu atau kelompok. Terpaan media berusaha mencari data khalayak tentang penggunaan media baik jenis media, frekuensi penggunaan maupun durasi penggunaan (longevity). ${ }^{2}$

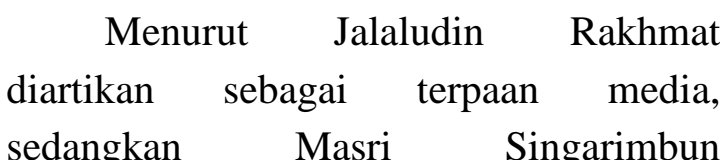
mengartikannya dengan sentuhan media. Menurut Rakhmat media exposure dapat dioperasionalkan sebagai frekuensi individu dalam menonton televisi, film, membaca majalah, atau surat kabar, amupun mendengarkan radio. Selain itu media exposure berusaha mencari data audiens tentang penggunaan media, baik jenis media, frekuensi penggunaan, maupun durasi penggunaan atau ion Gevity. ${ }^{3}$

$$
\text { Sedangkan Shore }
$$

memberikan definisi mengenai terpaan media adalah lebih lengkap daripada akses. Terpaan tidak hanya menyangkut apakah seseorang secara fisik cukup dekat dengan kehadiran media massa akan tetapi apakah seseorang tersebut benar- benar terbuka dengan pesan - pesan media tersebut. Terpaan merupakan kegiatan mendengar, melihat dan membaca pesan-pesan media

\footnotetext{
2 Ardianto Elvinaro, 2014, Komunikasi Massa Suatu Pengantar : Bandung, Simbiosa Rekatama. hlm 168

${ }^{3}$ Rakhmat, Jalaluddin, 2007. Psikologi Komunikasi , PT Remaja Rosdakarya, Bandung. Hlm 113
}

massa ataupun pengalaman dan perhatian terhadap pesan tersebut yang dapat terjadi pada individu maupun kelompok.

\section{Makna Berita}

Mitchel V. Charnley dalam bukunya Reporting edisi III (Holt-Reinhart \& Winston, New York, 1975 halaman 44) menyebutkan berita adalah laporan yang tepat waktu mengenai fakta atau opini yang memiliki daya tarik atau hal penting atau kedua-duanya bagi masyarakat luas. Dengan demikian dapat disimpulkan bahwa "berita adalah suatu fakta atau ide atau opini aktual yang menarik dan akurat serta dianggap penting bagi sejumlah besar pembaca, pendengar maupun penonton. ${ }^{4}$

Dari pengertian di atas, ada empat unsur yang harus dipenuhi oleh sebuah peristiwa, sehingga layak menjadi sebuah berita. Unsur-unsur tersebut adalah; 1) Unsur aktual, yakni Mengandung unsur terkini, terbaru, terhangat, baru saja atau sedang terjadi. Pengertian terbaru, bisa merupakan fakta terbaru yang ditemukan dari suatu peristiwa lama, atau peristiwa yang baru saja terjadi. 2) Unsur Faktual, Dalam unsur faktual, kejadian benar-benar merupakan suatu kenyataan, bukan suatu rekayasa, khayalan atau karangan. Fakta dalam sebuah berita muncul dan diperoleh dari sebuah kejadian nyata, pendapat ataupun pernyataan. 3). Unsur Penting, yaitu Ada dua hal dalam berita dinilai penting. Pertama tokoh yang terlibat dalam pemberitaan adalah tokoh penting atau

\footnotetext{
${ }^{4}$ Muda,, Deddy Iskandar 2005, Jurnalistik Televisi Menjadi Reporter Profesional, Remaja Rosda Karya, Bandung, hal. 21
} 
memiliki kapasitas yang telah diakui oleh masyarakat.Kedua, materi berita menyangkut kepentingan orang banyak dan mempengaruhi kondisi masyarakat. 4) Unsur Menarik, yakni menimbulkan rasa ingin tahu, dan ketertarikan dari masyarakat untuk menyimak isi berita tersebut. Peristiwa yang menarik dan diminati oleh masyarakat biasanya bersifat menghibur, aneh, memiliki unsur kedekatan, mengandung nilai kemanusiaan, mengandung unsur seks, kriminalitas dan konflik.

Komunikasi pembelajaran dapat efektif jika dilakukan dengan memenuhi elemen daya tarik, pemahaman, penerimaan, keterlibatan, dan keyakinan ${ }^{5}$. Lima elemen ini dapat dilakukan ketika penyampaian pesan dilakukan secara tatap muka langsung. Namun, ketika masa pandemi COVID-19 yang menerapkan pembelajaran jarak jauh berbasis internet, lima elemen ini dalam penerapannya menemui hambatan karena ruang gerak komunikator (guru) dan komunikasn (siswa) yang terbatas dalam pembelajaran daring. Pembelajaran daring yaitu proses transformasi pengetahuan dalam pembelajaran yang dilakukan dengan sistem penyebaran materi ajar secara terbuka dengan media pembelajaran berbasis jaringan internet yang kuat untuk melakukan interaksi pada saat proses pembelajaran berlangsung ${ }^{6}$. Kelancaran

5 Basori Basori, "Efektifitas Komunikasi Pembelajaran Online Dengan Menggunakan Media E-Learning Pada Perkuliahan Body Otomotif," Jurnal Ilmiah Pendidikan Teknik Dan Kejuruan 7, no. 2 (2017): 30.

${ }^{6}$ Novita Arnesti and Abdul Hamid, "Penggunaan Media Pembelajaran Online-Offline Dan pembelajaran daring ditunjang dengan adanya jaringan internet yang kuat, karena tanpa adanya jaringan internet yang kuat, maka pengajar dan peserta didik tidak dapat melangsungkan kegiatan belajar mengajar dengan baik ${ }^{7}$.

\section{Gejala-Gejala Kecemasan}

Pada dasarnya, kecemasan merupakan hal wajar yang pernah dialami oleh setiap manusia. Kecemasan sudah dianggap sebagai bagian dari kehidupan sehari-hari. Kecemasan adalah suatu perasaan yang sifatnya umum, dimana seseorang merasa ketakutan atau kehilangan kepercayaan diri yang tidak jelas asal maupun wujudnya.

Kecemasan adalah sesuatu yang menimpa hamper setiap orang pada waktu tertentu dalam kehidupannya. Kecemasan merupakan reaksi normal terhadap situasi yang sangat menekan kehisupan seseorang. Kecemasan bisa muncul sendiri atau bergabung dengan gejala-gejala lain dari berbagai gangguan emosi.

Menurut Kaplan, Sadock, dan Grebb (Fitri Fauziah dan Julianti Widuri) kecemasan adalah respon terhadap situasi tertentu yang mengancam, dan merupakan hal yang normal terjadi menyertai perkembangan, perubahan, pengalaman baru atau yang belum pernah dilakukan, serta dalam menemukan identitas diri dan arti hidup. Kecemasan adalah reaksi yang dapat dialami siapapun. Namun cemas

Komunikasi Interpersonal Terhadap Hasil Belajar Bahasa Inggris," Jurnal Teknologi Informasi \& Komunikasi Dalam Pendidikan 2, no. 1 (2015): 88.

7 Hakiman, "Pembelajaran Daring," accessed December 27, 2020, https://iainsurakarta.ac.id/\%EF\%BB\%BFpembelajarandaring. 
yang berlebihan, apalagi yang sudah menjadi gangguan akan menghambat fungsi seseorang dalam kehidupannya. ${ }^{8}$

Kecemasan merupakan suatu perasaan subjektif mengenai ketegangan mental yang menggelisahkan sebagai reaksi umum dari ketidakmampuan mengatasi suatu masalah atau tidak adanya rasa aman. Perasaan yang tidak menentu tersebut pada umumnya tidak menyenangkan yang nantinya akan menimbulkan atau disertai perubahan fisiologis dan psikologis.

Namora Lumongga Lubis menjelaskan bahwa kecemasan adalah tanggapan dari sebuah ancaman nyata ataupun khayal. Individu mengalami kecemasan karena adanya ketidakpastian dimasa mendatang. Kecemasan dialami ketika berfikir tentang sesuatu tidak menyenangkan yang akan terjadi. Sedangkan memahami kecemasan sebagai suatu keadaan yang menggoncangkan karena adanya ancaman terhadap kesehatan.

Nevid Jeffrey S, Rathus Spencer A, \& Greene Beverly memberikan pengertian tentang kecemasan sebagai suatu keadaan emosional yang mempunyai ciri keterangsangan fisiologis, perasaan tegang yang tidak menyenangkan, dan kekhawatiran bahwa sesuatu yang buruk akan terjadi. ${ }^{9}$

Kecemasan adalah rasa khawatir, takut yang tidak jelas sebabnya.Kecemasan juga merupakan kekuatan yang besar dalam menggerakkan tingkah laku, baik

\footnotetext{
${ }^{8}$ Fitri, Fauziah, 2005. Psikologi Abnormal klinik dewasa, Jakarta : UI Pess.hlm 103.
}

tingkah laku yang menyimpang ataupun yang terganggu. Keduaduanya merupakan pernyataan, penampilan, penjelmaan dari pertahanan terhadap kecemasan tersebut

Kesimpulan yang dapat diambil dari beberapa pendapat diatas bahwa kecemasan adalah rasa takut atau khawatir pada situasi tertentu yang sangat mengancam yang dapat menyebabkan kegelisahan karena adanya ketidakpastian dimasa mendatang serta ketakutan bahwa sesuatu yang buruk akan terjadi.

Gejala-gejala yang bersifat fisik diantaranya adalah : jari tangan dingin, detak jantung makin cepat, berkeringat dingin, kepala pusing, nafsu makan berkurang, tidur tidak nyenyak, dada sesak.Gejala yang bersifat mental adalah;

Ketakutan merasa akan ditimpa bahaya, tidak dapat memusatkan perhatian, tidak tenteram, ingin lari dari kenyataan Kecemasan juga memiliki karakteristik berupa munculnya perasaan takut dan kehati-hatian atau kewaspadaan yang tidak jelas dantidak menyenangkan.

Gejala-gejala kecemasan yang muncul dapat berbeda pada masing-masing orang. Kaplan, Sadock, \& Grebb (Fitri Fauziah \& Julianti Widury, 2007:74) menyebutkan bahwa takut dan cemas merupakan dua emosi yang berfungsin sebagai tanda akan adanya suatu bahaya. Rasa takut muncul jika terdapat ancaman yang jelas atau nyata, berasal dari lingkungan, dan tidak menimbulkan konflik bagi individu. Sedangkan kecemasan muncul jika bahaya berasal dari

9 Nevid. J.S, Rathus, S.A. and Greene, B. 2005. Psikologi Abnormal (Alih Bahasa : Jeanette Mura,dkk). Jakarta : Erlangga. Hlm 119. 
dalam diri, tidak jelas, atau menyebabkan konflik bagi individu..

Kecemasan berasal dari perasaan tidak sadar yang berada didalam kepribadian sendiri, dan tidak berhubungan dengan objek yang nyata atau keadaan yang benar-benar ada mengemukakan beberapa gejala-gejala dari kecemasan antara lain; ${ }^{10}$

Pertama, Ada saja hal-hal yang sangat mencemaskan hati, hampir setiap kejadian menimbulkan rasa takut dan cemas. Kecemasan tersebut merupakan bentuk ketidakberanian terhadap hal-hal yang tidak jelas. Kedua, Adanya emosiemosi yang kuat dan sangat tidak stabil. Suka marah dan sering dalam keadaan exited (heboh) yang memuncak, sangat irritable, akan tetapi sering juga dihinggapi depresi.

Ketiga, Diikuti oleh bermacammacam fantasi, delusi, ilusi, dan delusion of persecution (delusi yang dikejar-kejar). Keempat, Sering merasa mual dan muntahmuntah, badan terasa sangat lelah, banyak berkeringat, gemetar, dan seringkali menderita diare. Kelima, Muncul ketegangan dan ketakutan yang kronis yang menyebabkan tekanan jantung menjadi sangat cepat atau tekanan darah tinggi.

\section{Metode Penelitian}

Pendekatan penelitian yang digunakan dalam skripsi ini adalah penelitian kuantitatif. Penelitian kuantitatif adalah sumber data dalam bentuk angka-

${ }^{10}$ Fitri, Fauziah, 2005. Psikologi Abnormal klinik dewasa, Jakarta : UI Pess.hlm 107

${ }_{11}$ Sukandarrumudi, Metodologi Penelitian Petunjuk Praktis untuk Peneliti Pemula, angka. $^{11}$ Metode penelitian kuantitatif merupakan salah satu jenis penelitian yang spesifikasinya adalah sistematis, terencana, dan terstruktur dengan jelas. Jenis penelitian yang digunakan adalah penelitian survey atau lapangan, yaitu penelitian yang dilakukan pada populasi besar maupun kecil. Dengan menghimpun data penelitian, data-data penelitian tersebut dapat diamati oleh peneliti.

\section{Hasil dan Pembahasan \\ Profil UIN Sunan Ampel Surabaya}

UIN Sunan Ampel adalah salah satu Perguruan Tinggi Negeri di Surabaya yang mengkhususkan kajian dalam bidang studi Islam. UIN Surabaya diberi nama Sunan Ampel yang merupakan salah satu seorang Walisongo, tokoh penyebar Islam di Indonesia UIN Sunan Ampel didiirikan pada tanggal 5 juli 1965 dengan Keputusan Menteri Agama no. 20/1965. Pendiri UIN Sunan Ampel Surabaya ini berawal dari gagasan para tokoh di Jawa Timur yang mengingnkan dibentukna Perguruan Tinggi yang bernaug di bawah pembinaan Departemen Agama. Hal ini terjadi pada akhir dekade 1950-an, yang kemudian ditindak lanjuti dengan adanya pertemuan di lembaga pada tahun 1961.

Dalam pertemuan itu, Profesor Soenarjo selaku Rektor UIN Sunan Kalijaga Yogyakarta hadir sebagai nara sumber untuk menyampaikan pokokpokok pikiran yang di perlukan sebagai landasan berdirinya Perguruan Tinggi agama Islam. Dalam sesi akhir pertemuan

(Yogyakarta: Gajah Mada University, 2004), hlm 63 
bersejarah tersebut, forum mengesahkan beberapa keputusan penting yaitu: (1) membentuk panitia pendirian UIN, (2) Mendirikan Fakultas Syari'ah di Surabaya, dan (3) Mendirikan Fakultas Tarbiyah di Malang. Selanjutnya, pada tanggal 9 Oktober 1961, di bentuk Yayasan Badan Wakaf Kesejahteraan Fakultas Sari'ah dan Fakultas Tarbiyah yang menyusun rencana kerja sebagai berikut :

Pertama, Mengadakan persiapan pendrian UIN Sunan Ampel yang terdiri dari Fakultas Syari'ah di Surabaya dan Fakultas Tarbiyah di Malang. Kedua, Menyediakan tanah untuk pembanguna Kampus UIN Sunan Ampel seluas 8 (delapan) Hektar yang terletak di Jalan Ahmad Yani No. 117 Surabaya. Ketiga, Menyediakan beberapa rumah dinas bagi para Guru Besar UIN Sunan Ampel Surabaya.

Pada tanggal 29 Oktober 1961, menteri Agama menerbitkan Surat Keputusan dengan No. 17/1961, untuk mengesahka pendirian Fakultas Syari'ah di Surabaya dan Fakultas Tarniyah di Malang. Kemudian pada tanggal 01 Oktober 1964, pendirian Fakultas Ushuluddin di Kediri diresmikan berdasarkan SK Menteri Agama NO. 66/1964.

Berawal dari 3 Fakultas tersebut, Menteri Agama memandang perlu untuk mengeluarkan SK No. 20/1965 tentang pendirian UIN Sunan Ampel yang berkedudukan di Surabaya. Sejarah mencatat bahwa tanpa membutuhkan waktu yang panjang, UIN Sunan Ampel ternyata mampu berkembang dengan pesat. Dalam rentang waktu antar 1966-1970,
UIN Sunan Ampel telah memiliki 18 fakultas yang tersebar di 3 Provinsi : Jawa Timur, Kalimantan Timur, dan Nusa Tenggara Barat.

Namun ketika akreditasi Fakultas 3 dari 18 Fakultas yang dimiliki UIN Sunan Ampel ditutup dan kemudian digabungkan dengan fakutas lain yang terakreditasi dan berdekatan lokasinya. Selanjutnya dengan adanya peraturan pemerintah nomor 33 tahun 1985, Fakultas Tarbiyah Samarinda dilepaskan pengelolahanya dari UIN Suan Ampel Surabaya serta diserahkan ke IAIN Banjarmasin. Demikian pula, Fakultas Tarbiyah Bojonegoro dipindahkan ke Surabaya dan statusnya berubah menjadi Fakultas Tarbiyah UIN Surabaya. Dalam pertumbuhan selanjutnya, UIN Sunan Ampel memiliki 12 fakultas tersebar di seluruh Jawa Timur dan 1 fakultas di Mataram, Lombok, Nusa Tenggara Barat. Namun pada saat ini, UIN Sunan Ampel berkonsenrasi pada 5 fakultas induk yang semuanya berlokasi di kampus Surabaya.

Visi dan Misi dan Motto UIN Sunan Ampel Surabaya. Sebagai lemabaga pendidikan tinggi, UIN Sunan Ampel memiliki visi, misi, dan motto yang menjadi landasan dan dasar dalam setiap aktivitasnya, sebagaimana yang dituangkan dalam Keputusan Menteri Agama Republik Indonesia Nomor 29 tahun 2008 tentang STATUTA UIN Sunan Ampel Visi UIN Sunan Ampel Surabaya adalah menjadi pusat pengembangan ilmuilmu keislaman multidisiplin yang tungal dan kompetitif.

Dalam mewujudkan pernyataan visi tersebut, UIN Sunan Ampel memiliki beberapa misi yang dijadikan arahan dalam 
pengambilan kebijakan mereka antara lain;

1) Menyelenggarakan pendidikan ilmuilmu keislaman, yang memiliki keunggulan dan daya saing internasional. 2) Melakukan pengembangan riset ilmu keislaman, social serta humaniora yang memiliki relevansi dengan kebutuhan masyarakat. 3) Mengembangkan pola pemberdayaan masarakat berbasis religiutas. 4) Menciptakan lulusan yang berstandar kompetensi akademik serta memiliki profesionalitas tinggi. Sedangkan Motto UIN Sunan Ampel adalah berwawasan global dan berbudi luhur.

\section{Perolehan Angket}

Sebelum data disajikan sebagaimana tujuan penelitian yaitu ingin mengetahui ada tidaknya pengaruh menonton tayangan berita tentang kasus pembegalan motor terhadap tingkat kecemasan mahasiswa UIN Sunan Ampel Surabaya. Kalau ada, seberapa besar pengaruh tersebut, maka peneliti akan mengemukakan hal-hal tersebut diatas berdasarkan jawaban responden melalui koesioner.

Data yang akan disajikan adalah data dari koesioner yang telah disebarkan kepada mahasiswa UIN Sunan Ampel Surabaya yang telah menjadi sample dalam penelitian ini. Untuk variabel $\mathrm{x}$ diberikan 10 pertanyaan, dan variabel y diberikan 10 item pertanyaan yang terkait. Dalam setiap pertanyaan disediakan 3 alternatif jawaban yang masing - masing jawaban mempunyai bobot yang berbeda, diantaranya yaitu sangat setuju (3), setuju (2), Tidak setuju (1). Dengan menyediakan 3 alternatif jawaban tersebut diharapkan responden mampu memberikan jawaban yang relevan terhadap pokok-pokok persoalan yang dibahas tanpa menemui kesulitan.

Sejumlah data diketahui, maka langkah selanjutnya yang akan dilakukan peneliti adalah menguji data tersebut dengan program SPSS 16.0 untuk mengetahui ada tidaknya pengaruh pengaruh menonton tayangan berita pembegalan motor terhadap tingkat kecemasan mahasiswa UIN Sunan Ampel Surabaya. Dengan demikian dalam penelitian ini akan digunakan rumus product moment correlation, sedangkan untuk mengetahui secara pasti hasil dari analisis rumus product moment secara signifikan mengenai menonton tayangan berita pembegalan motor terhadapn tingkat kecemasan mahasiswa UIN Sunan Ampel Surabaya digunakan rumus uji signifikan koefisien korelasi sederhana.

\section{Hasil Pengujian Hipotesis}

Hipotesa adalah jawaban sementara atas pertanyaan penelitian. Dengan demikian, ada keterkaitan antara perumusan masalah dengan hipotesis, karena perumusan masalah merupakan pertanyaan penelitian.

Untuk mengetahui pengaruh terpaan media televisi tentang berita pembegalan motor terhadap tingkat kecemasan mahasiswa prodi Ilmu Komunikasi UIN Sunan Ampel Surabaya, maka penulis akan menyajikan olahan data dari hasil 
penyebaran angket antara variable $(\mathrm{x})$ dan variable (y).

Dalam hal ini pengujian hipotesis dilakukan dengan menggunakan rumus product moment dan telah dikemukakan bahwa hipotesis yang diajukan dalam penelitian ini adalah terdapat pengaruh yang signifikan antara pengaruh menonton berita pembegalan motor terhadap tingkat kecemasan mahasiswa UIN Sunan Ampel Surabaya. Untuk melakukan pengujian hipotesis tersebut, maka dilakukan analisis data dengan menggunakan rumus product moment dengan menggunakan bantuan program Statistical Package For Social Sciene (SPSS) versi 16,0 for windows.

Berdasarkan output SPSS, pengaruh terpaan media televisi tentang pemberitaan kasus pembegalan motor terhadap tingkat kecemasan mahasiswa UIN Sunan Ampel ditunjukkan pada tabel berikut;

\begin{tabular}{|c|c|c|c|}
\hline & Mean & $\begin{array}{c}\text { Std. } \\
\text { Deviation }\end{array}$ & $\mathrm{N}$ \\
\hline $\begin{array}{c}20.800 \\
\text { menonton_berita } \\
\text { tingkat_kecemas } \\
\text { an }\end{array}$ & $\begin{array}{c}23.760 \\
0\end{array}$ & 4.20398 & 30 \\
& 6.02566 & 30 \\
\hline
\end{tabular}

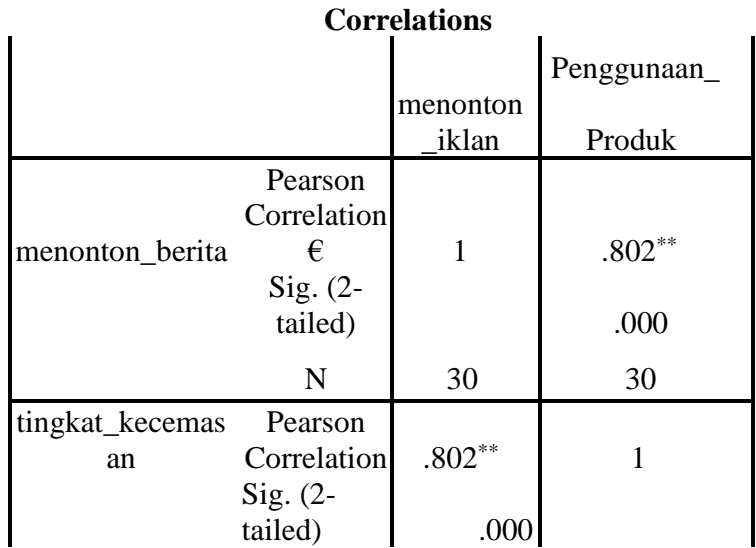

**. Correlation is significant at the 0.01 level (2tailed)
Interpretasi output spss :

1. Pada tabel correlation diperoleh harga koefisien sebesar 0,802 dengan signifikan sebesar 0,000.

2. Berdasarkan data diatas maka dapat dilakukan pengujian hipotesis dengan membandingkan taraf signifikansi (p-value) dengan galatnnya (galat/p) - 0,05 atau 5\%.

3. Koefisien korelasi pada penelitian ini bisa dilihat pada tabel yaitu 0,802 dengan signifikasi 0,000 . Karena signifikansi < 0,05 maka Ho ditolak dan $\mathrm{Ha}$ diterima. Artinya ada hubungan kuat antara terpaan media televisi tentang pemberitaan kasus pembegalan motor dengan tingkat kecemasan mahasiswa.

4. Hasil analisis korelasi product moment tersebut signifikan, maka perlu dibandingkan dengan $r$ tabel.

5. Jika $\mathrm{r}$ hitung kepercayaannya 0,05 (5\%), maka dapat diperoleh harga $r$ tabel sebesar 0,802. Ternyata $r$ hitung lebih kecil dari $\mathrm{r}$ tabel $(0,802>0,284)$, sehingga h0 ditolak dan ha diterima. Artinya ada pengaruh antara menonton menonton tayangan pembegalan motor terhadap tingkat kecemasan mahasiswa.

Dalam penelitian ini,untuk mengetahui hasil analisis product moment secara signifikan, maka peneliti menggunakan langkah-langkah uji signifikansi korelasi sederhana (uji-t) sebagai berikut; 
1. Menentukan hipotesis

Ho : tidak ada pengaruh secara signifikan antara terpaan media televisi tentang pemberitaan kasus pembegalan motor terhadap tingkat kecemasan mahasiswa prodi ilmu komunikasi UIN Sunan Ampel Surabaya.

Ha: ada pengaruh secara signifikan antara antara terpaan media televisi tentang pemberitaan kasus pembegalan motor terhadap tingkat kecemasan mahasiswa prodi ilmu komunikasi UIN Sunan Ampel Surabaya

2. Menentukan tingkat signifikansi Pengujian menggunakan uji dua sisi dengan tingkat signifikansi $\mathrm{a}=5 \%$ (uji dilakukan 2 sisi karena untuk mengetahui ada atau tidaknya pengaruh antara terpaan media televisi tentang pemberitaan kasus pembegalan motor terhadap tingkat kecemasan mahasiswa prodi ilmu komunikasi UIN Sunan Ampel Surabaya. Yang signifikansi, jika 1 sisi digunakan untuk mengetahui hubungan lebih kecil atau lebih besar). Tingkat signifikansi dalam hal ini berarti peneliti mengambil resiko yang benar sebanyakbanyaknya 5\% (signifikansi 5\% atau 0,005 adalah ukuran standar yang sering digunakan dalam penelitian.

3. Menentukan $t$ hitung rumus uji-t

4. Menentukan $r$ tabel

Tabel distribusi $\mathrm{T}$ dicari pada $\mathrm{a}=5$ $\%: 2=2,5 \%$ (uji 2 sisi) dengan derajat kebebasan $(\mathrm{df})=\mathrm{n}-2$ atau 30 $-2=28$. Dengan pengujian 2 sisi
( signifikansi $=0,025)$ hasil diperoleh untuk $\mathrm{t}$ tabel sbesar 2,021

5. Membandingkan $t$ hitung dengan $t$ tabel dan probabilitas

Nilai hitung > tabel yaitu 9,306 > 2,021 dan $\mathrm{p}$ value yaitu $0,000<$ 0,005, maka Ho ditolak

6. Gambar

$\begin{array}{cc}\text { Ho di tolak } & \text { Jangan Tolak Ho } \\ & 95 \% \\ & \text { Tolak Ho Diterima }\end{array}$

7. Kesimpulan

Oleh karena $\mathrm{t}$ hitung $>\mathrm{t}$ tabel $(9,306>2,021)$ dan $p$ value $(0,000<0,05)$ maka ho ditolak dan ha diterima. Artinya bahwa antara terpaan media televisi tentang pemberitaan kasus pembegalan motor berpengaruh terhadap tingkat kecemasan mahasiswa prodi ilmu komunikasi UIN Sunan Ampel Surabaya karena $t$ hitung nilainya positif, berarti pengaruh antara terpaan media televisi tentang pemberitaan kasus pembegalan motor terhadap tingkat kecemasan mahasiswa prodi ilmu komunikasi UIN Sunan Ampel Surabaya bernilai positif dan signifikan. Jadi, dapat disimpulkan bahwa terpaan media televisi tentang pemberitaan kasus pembegalan berhubungan positif motor terhadap tingkat kecemasan mahasiswa prodi ilmu komunikasi UIN Sunan Ampel Surabaya

\section{Analisis Hasil Penelitian}

1. Uji Reliabilitas menunjukkan bahwa nilai Cronbach Alpha dari variable penggunaannya bagi mahasiswa (Y) lebih besar dari 0,284 yang berarti bahwa kuesioner yang merupakan 
indikator-indikator dari variabel tersebut adalah reliabel. Hal tersebut dapat dilihat dari hasil pengujian yang telah dilakukan dengan nilai Cronbach Alpha sebesar 0,947. Sementara itu uji reliabilitas untuk variabel menonton berita pembegalan motor (X) menggunakan nilai Cronbach Alpha. Uji Reliabilitas menunjukkan bahwa nilai Cronbach Alpha dari variabel menonton berita pembegalan motor (X) lebih besar dari 0,284 yang berarti bahwa kuesioner yang merupakan indikator-indikator dari variabel tersebut adalah reliabel atau handal. Hal tersebut dapat dilihat dari hasil pengujian yang telah dilakukan dengan nilai Cronbach Alpha sebesar 0,886 .

2. Uji Validitas menunjukkan bahwa nilai $r$ hitung dari masing-masing variabel lebih besar dari $\mathrm{r}$ tabel sebesar 0,284 dan tingkat signifikansi dari masing-masing variabel sebesar 0,05. Pada variabel menonton berita pembegalan motor (X) terdapat 9 item pernyataan yang dikatakan valid, sedangkan untuk variabel tingkat kecemasan mahasiswa (Y) terdapat 10 item pernyataan yang dikatakan valid.

3. Dalam analisis data ini, diperoleh jawaban bahwa menonton berita pembegalan motor ada pengaruh terhadap tingkat kecemasan mahasiswa. Dimana, hasil hipotesis nihil diterima dan terbukti setelah menghitung menggunakan rumus product moment dan telah diketahui juga hasil pengaruhnya secara signifikan melalui uji-t.

Berdasarkan hasil koefisien korelasinya yaitu 0,802. Maka ada pengaruh antara terpaan media televisi tentang pemberitaan kasus pembegalan motor terhadap tingkat kecemasan mahasiswa prodi ilmu komunikasi UIN Sunan Ampel Surabaya.

Untuk mengetahui seberapa besar pengaruh interpretasinya, langkah selanjutnya memberikan interpretasi terhadap $\mathrm{r}_{\mathrm{xy}}$, menggunakan interpretasi product moment. Hasil perhitungan menunjukkan bahwa nilai $\mathrm{r}$ adalah 0,802 .

Dalam perhitungan melalui product moment yang memperoleh hasil 0,802 , maka dapat menjawab rumusan masalah bahwa pengaruh antara terpaan media televisi tentang pemberitaan kasus pembegalan motor terhadap tingkat kecemasan mahasiswa prodi ilmu komunikasi UIN Sunan Ampel Surabaya memiliki pengaruh yang kuat.

\section{Kesimpulan}

Berdasarkan penelitian dan hasil analisis yang telah dilakukan tentang pengaruh terpaan media televisi tentang pemberitaan kasus pembegalan motor terhadap tingkat kecemasan mahasiswa prodi ilmu komunikasi UIN Sunan Ampel Surabaya. Maka diperoleh beberapa kesimpulan sebagai berikut;

Berdasarkan hasil korelasi product moment yang telah dilakukan pada penelitian ini, diperoleh harga koefisien 0,802 Kemudian hasil korelasi product 
moment tersebut dibandingkan dengan $\mathrm{r}$ tabel, dimana $r$ tabel dengan $\mathrm{n}=30$ adalah 0,284 . Jadi, hasilnya adalah $0,802>0,284$. Yang berarti h0 ditolak dan ha diterima yang artinya ada hubungan antara terpaan media televisi tentang pemberitaan kasus pembegalan motor terhadap tingkat kecemasan mahasiswa prodi ilmu komunikasi UIN Sunan Ampel Surabaya. Adanya hubungan atau tidak, juga dapat dilihat pada tabel correlation product moment, dimana nilai signifikansi bernilai 0,000 yang artinya h0 ditolak dan ha diterima.

Untuk mengetahui apakah ada pengaruh secara signifikan atau tidak antara terpaan media televisi tentang pemberitaan kasus pembegalan motor terhadap tingkat kecemasan mahasiswa prodi ilmu komunikasi UIN Sunan Ampel Surabaya, maka peneliti menggunakan uji korelasi sederhana (uji-t), dimana nilai $t$ hitung > t tabel, 9,306>2,021 dan $p$ value $0,000<0,005$, maka h0 ditolak dan ha diterima, artinya dapat disimpulkan bahwa terpaan media televisi tentang pemberitaan kasus pembegalan motor berpengaruh terhadap tingkat kecemasan mahasiswa prodi ilmu komunikasi UIN Sunan Ampel Surabaya.

\section{Daftar Pustaka}

Ardianto Elvinaro, 2014, Komunikasi Massa Suatu Pengantar: Bandung, Simbiosa Rekatama.

Atkinson Rita L, Richard C Atkinson dan Ernest R Hilgard (Eds). 1996. Pengantar Psikologi. PT Gelora Aksara Pratama.

Bagong Suyanto, 2006. MetodePenelitian Sosial
Berbagai Alternative Pendekatan, Jakarta: Rajawali Press.

Choli Narbuko, 2009. Metodologi Penelitian, Jakarta: PT. Bumi Aksara, 2009.

Effendi, Unong uchjana. 1992. Ilmu Komunikasi, Teori dan Praktek. Bandung: PT. Remaja Rosda karya.

Fitri, Fauziah, 2005. Psikologi Abnormal klinik dewasa, Jakarta : UI Pess.

Husein Umar, 2003. Metode Penulisan Skripsi dan Tesis, Jakarta: Angkasa.

Irawan Soehartono, $1995 . \quad$ Metode Penelitian Sosial, Cet. III, Bandung, PT. Remaja Rosdakarya.

Imam Ghozali,2001. Aplikasi Analisis dengan Program SPSS, Semarang: Universitas Diponegoro.

Jonathan Sarwono, 2006. MetodePenelitian Kuantitatif dan Kualitatif, Yogyakarta: Graha Ilmu.

J. Supranto, 2001. Statistik Teori dan Aplikasi, Jilid 2. Ed. 4 Jakarta: Erlangga, 2001.

Kartini Kartono, 1995. GangguanGangguan Kejiwaan, Jakarta: Raja Grafindo Persada.

Muda,, Deddy Iskandar 2005, Jurnalistik Televisi Menjadi Reporter Profesional, Remaja Rosda Karya, Bandung.

M. Hasan, 2002. Pokok-Pokok Materi Statistik, Edisi ke-2 Jakarta: Bumi Aksara, 2002.

Muhammad, 2008. Metodologi Penelitian Pendekatan Kuantitatif, Jakarta: Rajawali Pers.

Nevid. J.S, Rathus, S.A. and Greene, B. 2005. Psikologi Abnormal (Alih Bahasa: Jeanette Mura,dkk). Jakarta: Erlangga 
Rakhmat, Jalaluddin, 2007. Psikologi Komunikasi , PT Remaja Rosdakarya, Bandung.

Fisher, B. Aubrey, 1989, Teori-teori Komunikasi, Soejono Trimo (penerjemah) Bandung: Remadja Karya.

Saifuddin Azwar, 2003. Validitas dan Reabilitas, Yogyakarta: Pustaka Pelajar.

Savitri Ramiah, 2003. Kecemasan, Jakarta: Pustaka Belajar.

Sugiyono, 2011. Statistika untuk Penelitian, Bandung:Alfabeta.

Suharsimi Arikunto, 2006. Prosedur Penelitian Suatu Pendekatan Praktek, Jakarta: Rineka Cipta.

Suryabrata, Sumandi . 2008. Psikologi kepribadian. Jakarta : Raja Grafindo Persada.

Sukandarrumudi, 2004. Metodologi Penelitian Petunjuk Praktis untuk Peneliti Pemula, Yogyakarta: Gajah Mada University.

Suryabrata, S. 1990. Pengembangan Alat Ukur Psikologis. Yogyakarta : Andi Offset.

Syofian Siregar, 2012. Statistika Parametik untuk Penelitian Kuantitatif, Jakarta; Bumi Askara

Turmudi dan Sri Harini, 2008. Metode Statistika Pendekatan Teoritis dan Aplikatif, Malang: UIN Malang Press

Anwar, Kasrul, and Hendra Harmi. Perencanaan Sistem Pembelajaran Kurikulum Tingkat Satuan Pendidikan (KTSP). Bandung: CV Alfabeta, 2011.

Arnesti, Novita, and Abdul Hamid. "Penggunaan Media Pembelajaran Online-Offline Dan Komunikasi Interpersonal Terhadap Hasil Belajar Bahasa Inggris.” Jurnal Teknologi
Informasi \& Komunikasi Dalam Pendidikan 2, no. 1 (2015): 85-99. 